UDK: 811.111:811.163.4

Original scientific paper

Nadja Skopljak - Vildana Dubravac

Received on January 26th, 2019

International Burch University Sarajevo, English Department International Burch University Sarajevo, English Department /

University of Zenica

nadjaskopljak@hotmail.com - mujcicvildana@yahoo.com

\title{
THE IMPACT OF ENGLISH ON THE BOSNIAN LANGUAGE AND THE USE OF ENGLISH WORDS IN BOSNIAN
}

\section{Abstract}

The present study investigated the impact of English as the global language on Bosnian with a particular focus on the use of English words among adult Bosnian speakers. Thus, the survey was administered to 200 participants to get an insight into their preferences for native Bosnian words, foreign English words and adapted English words. The analysis revealed that English has gained a prominent status in Bosnia and Herzegovina, not rarely being preferred over the native structures with a similar or equivalent meaning. Furthermore, filling lexical gaps does not seem to motivate borrowing, but rather a wish to transmit a message of a more modern lifestyle.

Keywords: Bosnian; cross-linguistic influence; English; borrowing; preferences

\section{Introduction}

Being used more than any other language has ever been, including French and Latin, English has found its prominent status in today's 
modern world as a common global language (cf. Crystal, 2003). In fact, there has never been a language so extensively used for such a long period of time, so it has become the dominant language internationally in numerous fields like business, banking, music, tourism, academics, and so on (cf. Cavalheiro, 2015; Graddol, 200o), with a quarter of the world's population being fluent or competent in English (cf. Crystal, 2003). With such vast spread, it is being affected in many ways, but also acts as an influencer itself, serving worldwide as a donor language. This influence, visible mainly at the lexical level, has been greatly extended due to the daily use of technological tools facilitating communication both with people close and far from us. Among various technological tools, social networks stand out in terms of their impact on the language use, specifically Facebook as one of the most famous social network currently (cf. Cheung et al., 2011), incorporating all multimedia such as photos, videos, chats, etc., and Instagram as an extensively-used social network on the Balkans.

Thus, the study attempted to give an insight into the participants' preferences when given a choice between native and foreign adapted or non-adapted words, as well as into which groups of the participants with respect to their age tend to use English most readily. The ultimate purpose was, however, to broaden the scope of research of cross-linguistic influences of English on other languages awakening the interest of researchers in the increasing impact of the global language on other, less spoken, languages of the world.

\subsection{The Concept of Borrowing}

Hoffer (2002) defines borrowing as "the process of importing linguistic items from one linguistic system into another, a process that occurs any time two cultures are in contact over a period of time" (p. 1). Due to the technological expansion this contact is established much more easily so the impact of today's global language seems to be more widespread than the impact of the languages having enjoyed a similar status earlier. One of the primary reasons borrowing takes place is filling a 
semantic gap in vocabulary, i.e. due to the lack of appropriate terms in a receiving language, the words are borrowed from a source language to express the given idea or concept (cf. Trask, 1996). These novelties are usually indicated by nouns, and that might be the reason why they are on the top of the list of borrowed words. Far fewer are adjectives, verbs and words belonging to other word classes. However, people also look at language as a prestigious notion, so by associating the knowledge of English with education, business and success, users start consciously transferring structures from the target to their native language, making the second language to the first language impact in comparison to the first language to second language influence more cognitive and pragmatic (cf. Cook, 2003).

Once a language borrows a word, it can either retain its original form or can be adjusted to the recipient language and its rules. Hence, Fantini $(1985,146)$ accounts that there are two levels of borrowing. The first is 'pure borrowing, when a word keeps all its features, and 'adjusted borrowing, when the word adapts to the recipient language. All of this depends on the features of the word and the phonological or orthographic rules of the recipient language, while the recipient language speakers also play a pivotal role in the process. Some like to adjust the word to their native language for the sake of keeping its authenticity and originality, while others might be eager to accept the original form with a desire for prestige and status. Similarly, Filipović (1990) discusses the stages in transition of words from the state of a borrowed to a loan word, mentioning the adaptation at the orthographic, phonological and morphological level. The author distinguishes between foreign words preserving all features of the source language diverse from those of the receiving language, foreign loans, the adaptation of which has started but is not yet complete, and loan words referring to those which are completely integrated into the native language system. In addition to the formal adaptation, the borrowings also undergo changes at a semantic level, with zero semantic extension, broadening and narrowing the meaning being among the most common (cf. Trask 1996). 
Although language change is a continuous and inevitable process, earlier it was much slower than it appears to be today, mostly due to technological advancement and the Internet, which have undoubtedly exerted the greatest impact on language in the $21^{\text {st }}$ century. Some researchers blame them for ruining language (cf. Drouin, 2011; Thurairaj et al. 2015), while some emphasize their importance in language development (cf. Craig, 2003; Omar - Miah, 2012). Whatever the case, the English language is nowhere close to what it was ten years ago, and the impact of the modern world comprising technology is best seen through English acting as an influencer (and a source language) on other languages.

\subsection{Cross-Linguistic Impact of English on $B / C / S$}

As seems to be the case with other languages (cf. Abdul Kadir Zubir, 2012; Gorlach, 2002; Thurairaj et al., 2015), Bosnian continues to borrow lexical material from English (Ajšić, 2014; Dubravac, 2016; Dropić, 2013; Hanić - Pavlović, 2007; Kajtazović, 2012; Šehović, 2009; Šljivić, 2006), usually referred to as Anglicisms, i.e. words transferred from English (cf. Filipović, 1990), as well as words denoting notions and objects of English origin and/or English and American lifestyle.

Exploring political discourse, Ajšić (2014) concluded that the most frequent type of loanwords are internationalisms, words which derive from Greek or Latin, for example, energija from energy, entitet from entity, etc. However, Klajn (2001) claims that Graeco-Latinisms entered Bosnian mostly through English, therefore they do receive the status of Anglicisms. Kajtazović's (2012) study showed that the influx of vocabulary related to music from English to Bosnian is a positive and developing process. She claimed that this is due to an easily accessible large number of loanwords found in magazines and on the web. The author emphasised the importance of borrowing music-related lexical items, because there are usually no equivalent native lexemes to the music terminology in the English language. Due to that lack of lexemes and adequate equivalents, it appears easier to simply borrow a word than to search out for an appropriate equivalent. As another reason for 
borrowing the author mentioned the popularity of English trends coming via the media, as well as using foreign terminology as a prestige symbol. Similarly, Hanić and Pavlović (2006) talked about Bosnian becoming English in computer technology, emphasising that this area of language presents one focus of interest for younger people who seem to be readily accepting and using Anglicisms in this domain.

The role of the media in disseminating English words has been a subject of a few studies (cf. Dubravac, 2016; Dropić, 2013; Šehović, 2009; Šljivić, 2006). The papers indicated that borrowings are usually adapted at the phonological, orthographic and morphological level to the Bosnian language system. Nonetheless, it was surprising that a large number of words used in their original form was discovered. Although the studies indicated the strongest influence at the lexical level, the impact was also observed at the morpho-syntactic level with a greater number of $\mathrm{N}_{1}+\mathrm{N}_{2}$ structures (cf. Dubravac, 2016, 214; Šljivić, 2006, 187) such as BiH film festival, fitness centar, Sarajevo biznis forum; the use of English suffixes: leasing, mastering, reper, lider, as well as the use of prefix e (e-uprava) (Dubravac 2016: 216); the omission of case endings: general vojske SAD, u centralnom dnevniku FACE TV sa ... (Dubravac, 2016, $217-218)$. Moreover, codemixing was emphasised as a quite common phenomenon: budi uvijek online, ovakve odluke u mom životu su uvijek bile breaking news (Dubravac, 2016, 215).

The studies investigating the influence of English on the languages spoken in the neighbouring countries, Serbia and Croatia, have reached the same conclusions, indicating an increased use of borrowings in the media (Brdar, 2010; Horvat, 2005), sports (Milić, 2004), medical discourse (Gjuran-Coha, 2005), and job-related terminology (Dobrić, 2008). Especially interesting in the context of the present study is the study carried out by Vlajković (2010), who analysed the language used on Facebook. The study revealed that the influence of English on the native, in this case the Serbian language, was visible in many ways, some of which were: the capitalisation of some words, as well as doubling of some letters not allowed in native but common to the English language, the use of transcribed English words, even the use of some English 
suffixes (like plural -s) and structure combinations not common to Serbian but following the patterns in English.

The present study attempted to show whether the same trends are followed by Bosnian speakers as social networks users. Thus, it was guided by the following research questions:

- RQ1: Do Bosnian speakers use English on social networking sites?

- RQ2: Do Bosnian native speakers prefer the use of borrowings related to Internet-based vocabulary or synonymous native words?

- RQ3: Does the use of borrowings related to Internet-based vocabulary or corresponding native words depend on the age of the participants?

\section{Methodology}

\subsection{Research Method and Instruments}

The data for this study were collected by a survey, administered in a hard copy form and comprising two parts. The first part, a background questionnaire, included seven questions related to the respondents' personal information such as gender, age, education level, English language knowledge, as well as the usage of English on Facebook. It also encompassed questions about how frequently they used English. The second part comprised ten multiple choice questions from which the respondents had to choose the word they used most often. Each of the ten answers offered a Bosnian word and an English word in its original form or a word adapted to the Bosnian sound and orthographic system. Since the participants had a different level of English knowledge, the instrument was in their mother tongue, i.e. in the Bosnian language.

\subsection{Participants}

The sampling procedure used for the selection of participants was criterion sampling, i.e. the participants were chosen based on the identified characteristics providing the necessary information for the study. 
In this case, the criteria were that the participants' mother tongue was Bosnian, that they had a Facebook profile and that they were more than 12 years old.

The research included 200 participants, 86 (43\%) of whom were male, and 114 ( $57 \%$ ) were female. 50 of them were aged from 12 to 19,50 from 20 to 30,50 from 31 to 40 , and 50 were older than 41 .

\section{Results and discussion}

The survey showed that, in addition to Bosnian, English is the second most prominent language used on social networking sites. Thus, out of 200 respondents, 93 reported they used Facebook in English, 96 in Bosnian, and only $5.5 \%$ claimed they used it in some other language (see Figure 1).

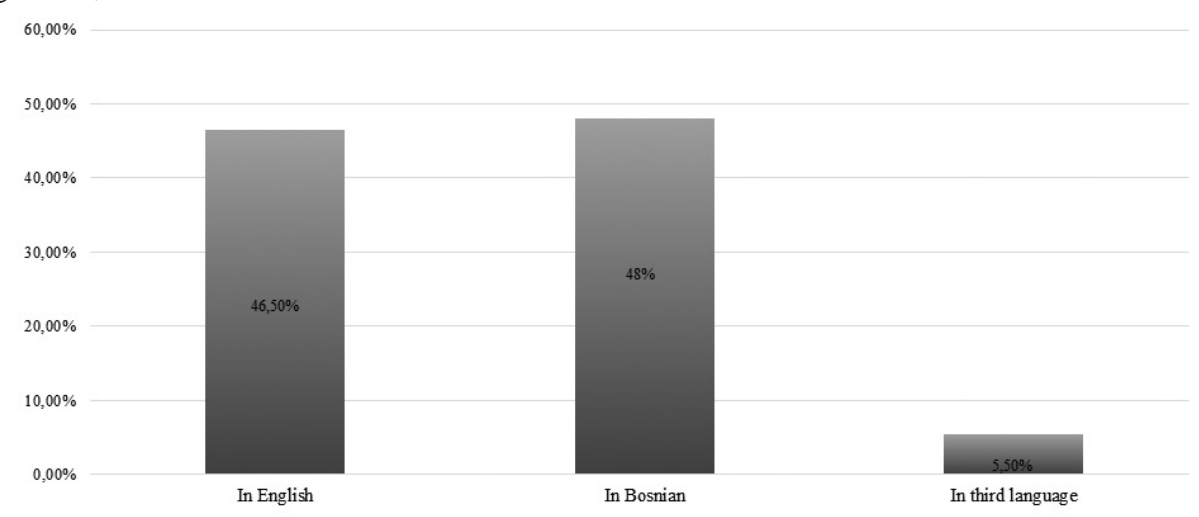

Figure 1. Facebook language frequency

The findings also showed that the majority of the participants were exposed to English, as 66 and 111 of them claimed they often read and listened to in English, respectively. 67 (33.5 \%) of them said that they sometimes read in English, while 73 of them said that they sometimes listened to something in English. 43 (21.5 \%) of them said that they rarely read in English and 13 (6.5\%) said that they rarely listened to something in English. Lastly, the minority, i.e. 24 (12\%) of them said that they never 
read in English, while a small number of $3(1.5 \%)$ said that they never listened to anything in English (see Figure 2).

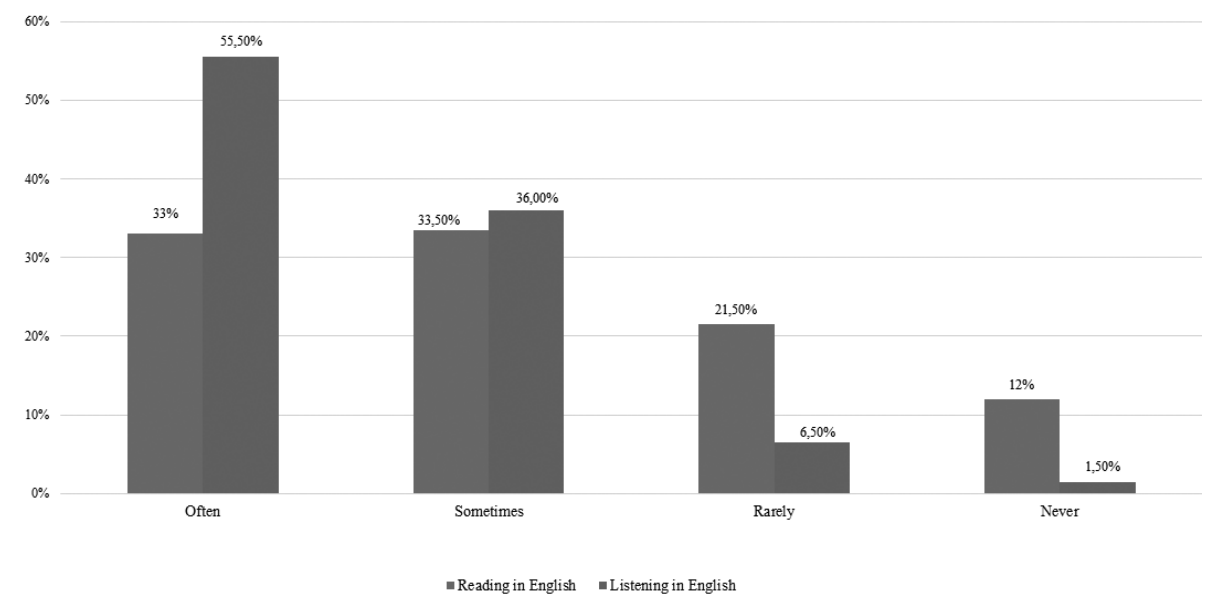

Figure 2. Frequency of Reading and Listening in English

The respondents' preferences were explored in a way that they were given a choice between English, adapted English and Bosnian words. However, when choosing the target structures, the focus was on the utterances users commonly encounter on social networks such as 'like - lajk - sviđa mi se, ' post - objava,' 'chat - čatati - dopisivati se', to name a few. The two figures below show the respondents' choices between English and Bosnian/English adapted words (see Figure 3) and between English words, adapted English words and Bosnian words (see Figure 4).

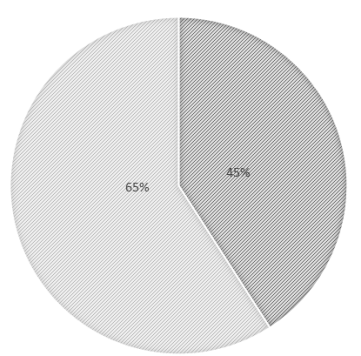

Figure 3. English vs. Bosnian/English

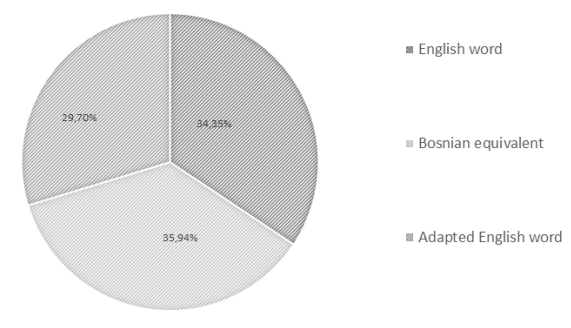

Figure 4. English vs. adapted English vs. Bosnian words 
The results suggest that when offered an English foreign word, an adapted English word and a Bosnian equivalent, $35.94 \%$ of the respondents chose a Bosnian equivalent, 34.35 \% chose an English word, while $29.70 \%$ chose an adapted version (Figure 4). Similarly, in the tasks in which English and Bosnian/English adapted words were offered, $65 \%$ of the respondents chose Bosnian/ English adapted words, while the remaining $45 \%$ chose foreign English words (Figure 3). The high percentage of the participants opting for the English words indicates that this language has become an indispensable part of our everyday life. Its presence has been already noticed in music, politics, computer technology, the media (Ajšić, 2014; Dropić, 2013; Dubravac, 2016; Hanić - Pavlović, 2007; Kajtazović, 2012; Šehović, 2009; Šljivić, 2006), so this study pointed to its presence in the aspect of communication via social networking sites. However, the participants' preferences were interesting since they first gave primacy to the native words, and then to the foreign non-adapted words while those adapted were the least popular, suggesting that these words are rather used as foreign words than as loanwords in the Bosnian language. The participants tended to feel more confident when using the words in their original form, which might be addressed to the fact that they had encountered these structures in their original form so many times that they felt no adaptation was necessary (Dubravac, 2016).

Similar results were reported in Dubravac (2016), with the participants expressing a stronger preference for native than for foreign words. However, when different age groups were compared, the younger participants were those who preferred English words and the older ones rather opted for the native equivalents. The present study also included 4 different age groups to check whether it presents an important factor in terms of their choices. There were 50 participants in each age group, however, as can be seen the number varied for different tasks since some of the questions were not answered by all the participants. The frequencies of their choices were calculated, and the results are displayed in Table 1 . As expected, the age groups 12-19 $(\mathrm{F}=82)$ and $20-30(\mathrm{~F}=85)$ mostly chose the adapted English words, followed by those non-adapted $(\mathrm{F}=$ 
$77, \mathrm{~F}=69$, respectively), while they used the Bosnian words significantly less often $(\mathrm{F}=2 \mathrm{O}, \mathrm{F}=39$, respectively). The age group 31-40 expressed preferences for the English words most often $(\mathrm{F}=69)$, closely followed by the Bosnian $(F=65)$ and adapted English words $(F=62)$. Not surprisingly, the age group 41-above opted for the Bosnian words the most frequently $(\mathrm{F}=90)$, while the adapted words were the least frequently chosen $(\mathrm{F}=42)$. The total sum of the results also indicated that the age group using the English words most frequently was 12-19 $(\mathrm{F}=77)$, while the age group using the adapted English words most frequently was 20-30 $(\mathrm{F}=85)$, and the age group using the Bosnian equivalents most often was 41-above $(\mathrm{F}=90)$. This suggests that the younger generations tend to be those who most readily accept new words, growing up with them, while the older generations, especially those over 41 , tend to rely more on the native language, probably not being so familiar with all the expressions popular nowadays among younger people. Furthermore, this implies that younger people strive towards following trends in order to be better accepted or cool, as the respondents of Araya and Gamboa's (2012) study emphasised. The users coming from this age group also wish to be able to easily follow the media, the Internet, as well as technological advancements, therefore giving us confirmation of just how "nativized" (Prćić, 2014, 145) they are becoming. Generally, the participants expressed stronger preferences for foreign words if they were nouns than if they were verbs, which is in agreement with the previously stated conclusion that nouns are on the top of borrowed words (Millward and Hayes 2012).

Table 1. Frequency of usage of English, adapted English and Bosnian words in terms of age

\begin{tabular}{|l|l|l|l|l|l|l|l|l|}
\hline & \multicolumn{2}{|l|}{$12-19$} & \multicolumn{2}{l}{$20-30$} & \multicolumn{2}{l|}{$31-40$} & \multicolumn{2}{l|}{ 41-above } \\
\cline { 2 - 10 } & $F$ & $\%$ & $F$ & $\%$ & $F$ & $\%$ & $F$ & $\%$ \\
\hline like & 21 & $42.9 \%$ & 21 & $42 \%$ & 22 & $44 \%$ & 14 & $29.2 \%$ \\
\hline lajk & 25 & $51 \%$ & 23 & $46 \%$ & 14 & $28 \%$ & 10 & $20.8 \%$ \\
\hline svida mi se & 3 & $6.1 \%$ & 6 & $12 \%$ & 14 & $28 \%$ & 24 & $50 \%$ \\
\hline
\end{tabular}




\begin{tabular}{|l|l|l|l|l|l|l|l|l|}
\hline share & 9 & $19.6 \%$ & 10 & $21.7 \%$ & 8 & $16.3 \%$ & 6 & $14 \%$ \\
\hline šerovati & 21 & $45.7 \%$ & 26 & $56.5 \%$ & 19 & $38.8 \%$ & 8 & $18.6 \%$ \\
\hline podijeliti & 16 & $34.8 \%$ & 10 & $21.7 \%$ & 22 & $44.9 \%$ & 29 & $67.4 \%$ \\
\hline & & & & & & & & \\
chat & 29 & $61.7 \%$ & 26 & $53.1 \%$ & 21 & $42.9 \%$ & 15 & $35.7 \%$ \\
\hline čatati & 9 & $19.1 \%$ & 3 & $6.1 \%$ & 9 & $18.4 \%$ & 4 & $9.5 \%$ \\
\hline dopisivati se & 9 & $19.1 \%$ & 20 & $40.8 \%$ & 19 & $38.8 \%$ & 23 & $54.8 \%$ \\
\hline & & & & & & & & \\
sticker & 18 & $38.3 \%$ & 12 & $25 \%$ & 18 & $37.5 \%$ & 9 & $20.9 \%$ \\
\hline stiker & 27 & $57.4 \%$ & 33 & $68.8 \%$ & 20 & $41.7 \%$ & 20 & $46.5 \%$ \\
\hline naljepnica & 2 & $4.3 \%$ & 3 & $6.3 \%$ & 10 & $20.8 \%$ & 14 & $32.6 \%$ \\
\hline
\end{tabular}

Note: The English word is presented first, then the adapted English word and lastly the Bosnian equivalent.

The results were similar when the respondent were given only a choice between foreign and either foreign adapted or native words (Table 2), with the age group 12-19 preferring the English over the Bosnian/ English adapted words $(\mathrm{F}=143)$, and the age group 20-30 opting for the Bosnian/English adapted words $(\mathrm{F}=149)$, although the overall number of the participants choosing the English words was very close $(\mathrm{F}=142)$. Furthermore, the age group 31-40 preferred Bosnian/ English words adapted $(\mathrm{F}=146)$, as well as the age group 41 -above $(\mathrm{F}=162)$. The sum of the frequencies showed that the age group 12-19 chose the English words most often among all the groups $(\mathrm{F}=143)$, while the age group 41-above decided on the Bosnian/English adapted the most frequently $(\mathrm{F}=162)$ when compared to the other groups, which, again, was not unexpected due to their lack of exposure or lack of interest to reach the prestige the youngsters strive towards.

However, as it can be seen from the data, the choices seemed to be item-specific. The foreign word Facebook was preferred over fejzbuk by all the groups, the native word zid was chosen by a larger number of the participants in all groups, and the adapted word smajli was more acceptable to all the participants than the word in its original form smiley. It might be claimed that since the pronunciation of the word smiley 
is represented in its adapted form, the respondents rather opted for it. However, the frequency of the word seems to present an important determinant affecting the participants' choice. Thus, they rather decided on Facebook, which is an extremely frequent word, while in the case of a choice between wall and zid, they chose the native word, the word wall not being so frequently encountered.

Table 2. Frequency of usage of English and Bosnian/foreign adapted words in terms of age

\begin{tabular}{|l|l|l|l|l|l|l|l|l|}
\hline & \multicolumn{2}{|l}{$12-19$} & \multicolumn{2}{l}{$20-30$} & \multicolumn{2}{l}{$31-40$} & \multicolumn{2}{l}{41 -above } \\
\cline { 2 - 12 } & $F$ & $\%$ & $F$ & $\%$ & $F$ & $\%$ & $F$ & $\%$ \\
\hline post & 30 & $61.2 \%$ & 39 & $79.6 \%$ & 24 & $53.3 \%$ & 13 & $34.2 \%$ \\
\hline objava & 19 & $38.8 \%$ & 10 & $20.4 \%$ & 21 & $46.7 \%$ & 25 & $65.8 \%$ \\
\hline tag & 41 & $87.2 \%$ & 35 & $72.9 \%$ & 28 & $58.3 \%$ & 14 & $35 \%$ \\
\hline označiti & 6 & $12.8 \%$ & 13 & $27.1 \%$ & 20 & $41.7 \%$ & 26 & $65 \%$ \\
\hline wall & 7 & $16.3 \%$ & 12 & $24.5 \%$ & 17 & $36.2 \%$ & 6 & $15.8 \%$ \\
\hline zid & 36 & $83.7 \%$ & 37 & $75.5 \%$ & 30 & $63.8 \%$ & 32 & $84.2 \%$ \\
\hline facebook & 27 & $58.7 \%$ & 26 & $52 \%$ & 37 & $75.5 \%$ & 24 & $58.5 \%$ \\
\hline fejzbuk & 19 & $41.3 \%$ & 24 & $48 \%$ & 12 & $24.5 \%$ & 17 & $41.5 \%$ \\
\hline video call & 25 & $53.2 \%$ & 19 & $39.6 \%$ & 16 & $33.3 \%$ & 10 & $25 \%$ \\
\hline video poziv & 22 & $46.8 \%$ & 29 & $60.4 \%$ & 32 & $66.7 \%$ & 30 & $75 \%$ \\
\hline smiley & 13 & $27.7 \%$ & 11 & $23.4 \%$ & 18 & $36.7 \%$ & 13 & $28.9 \%$ \\
\hline smajli & 34 & $72.3 \%$ & 36 & $76.6 \%$ & 31 & $63.3 \%$ & 32 & $71.1 \%$ \\
\hline
\end{tabular}

Note: The English word is presented first.

\section{Conclusion}

The present study indicates a strong presence of English on social networking sites. In fact, in addition to the participants' native language, English seems to be widely used as a common means of communication. Moreover, the majority of the respondents claimed to gain 
regular exposure to English, either in the written or spoken form. This suggests that following massive exposure to English new generations will demonstrate better English competences. This was confirmed by the survey results, indicating that the younger the participants are, the more preference for English expressions they show.

Thus, English words were the most popular among the youngest participants, those 12-19 years old, the native equivalents among the oldest group, i.e. those older than 40 . Interestingly, the middle aged groups $20-$ 30, and $31-40$, mainly opted for the adapted English words. This shows how gradually Bosnian speakers start accepting some foreign words as their own. In the era of English dominance achieved worldwide, this is not unexpected. Moreover, language contact has always results in numerous borrowings related to different aspects of life. However, the language contact was conditioned by physical contact, and in modern times the contact is not confined by any limits related to place, as thanks to technology people from different parts of the world communicate directly on daily basis. Thus, the influence of English is not limited to politics, the media, sport or any other specific domain, but it impacts all of them. Whatever our attitude towards the influx of English as foreign words into other less spoken languages in the world is, the first step is raising the awareness about the language contact in the modern era, marked by the technological development, and its consequences. One of the ways of doing so is through research as presented in the current study, which shows some general trends present in this part of the world.

\section{Bibliography}

- Abdul Kadir, Zaemah - Zubir, Zurina (2012) „Code-switching in E-distance Learning Education”, IPEDR, IACSIT Press, vol. XXXIV, pp. $22-27$.

- AJšić, Adnan (2014) „Postwar Constitutional Arrangement and the Co-occurrence Tendencies of Anglicisms in Contemporary Bosnian", Journal of Language and Politics, John Benjamins, vol. XIII, no. 1, pp. $21-50$. 
- Araya, Jacqueline - Gamboa, Beatriz (2012) „Technology and New Language Trends: The Role of the ESL Teacher", <https://www.wcupa.edu/KnowledgeCrossingBorders/2012/ PDF/6.1.1\%2oAraya\%2oand\%2oGamboa.pdf.>,

- Brdar, Irena (2010) „Engleske riječi u jeziku hrvatskih medija“, Lahor, Zagreb, vol. II, no. 10, pp. 217 - 232.

- Cavalheiro, Lili Lopes (2015) English as a Lingua Franca: Bridging the Gap between Theory and Practice in English Language Teaching, PhD dissertation, Universidade De Lisboa, Lisboa, Portugal.

- Cheung, Christy - Chiu, Pui-Yee - Lee, Matthew (2011) „Online Social Networks: Why do Students Use Facebook?", Computers in Human Behavior, Elseivier, vol. 27, no. 4, pp. 1337 - 1343.

- Cook, Vivian (2003) The Effect of L2 on L1, Multilingual Matters, Clevedon.

- Craig, David (2003) „Instant Messaging: The Language of Youth Literacy", The Boothe Prize Essays, pp. 118 - 119.

- Crystal, David (2003) English as a Global Language, Cambridge University Press, New York

- Dobrić, Nikola (2008) „Uticaj engleskog na nazive poslova”, Language, Literature and Globalization, Mišić, BILJANA - LoPIČIĆ, VeSNA (ed.), Alpen-Adria Universitat Klagenfurt, Faculty of Philosophy at the University of Nišs, Klagenfurt - Niš, pp. 35 - 316.

- Dropić, Muraza (2009) „Engleske posuđenice u dnevnim bosanskohercegovačkim novinama", Didaktički putokazi, Pegagoški fakultet Zenica, no. 65, pp. 8 - 12 .

- Drouin, Michelle (2011) "College Students' Text Messaging, Use of Textese and Literacy Skills", Journal of Computer Assisted Learning, Wiley, no. 27, pp. $67-75$.

- Dubravac, Vildana (2016) „The Impact of English on Language Use in the Bosnian Press", The Growth of English in Post-war 
Bosnia and Herzegovina, Buckingham, Louisa (ed.). Multilingual Matters, Bristol - New York - Toronto, pp. 203- 227

- Fantini, Alvino (1985) Language Acquisition of a Bilingual Child: a Sociolinguistic Perspective (to Age Ten). Multilingual Matters, Bristol.

- Filipović, Rudolf (1990) Anglicizmi u hrvatskom ili srpskom je$z i k u$, Školska knjiga, Zagreb.

- Gjuran-Coha, Anamarija (2005) „Prevedeni i neprevedeni anglicizmi u hrvatskoj medicinskoj terminologiji", Semantika Prirodnog Jezika i Metajezik Semantike, Granić, Jagoda (ed.), Hrvatsko društvo za primijenjenu lingvistiku, Zagreb - Split, pp. $243-251$.

- Görlach, Manfred (2002) English in Europe, Oxford University Press, Oxford.

- Graddol, David (200o) „The Future of English? A Guide to Forecasting the Popularity of the English Language in the 21st Century", The British Council, <http://www.teachingenglish.org.uk/ sites/teacheng/files/learning-elt-future.pdf.>

- Hahić, Jasmina - Pavlović, Tanja (2007) „Is Bosnian Becoming English in Computer Technology?", New Perspectives: Essays on Language, Literature and Methodology, University of Montenegro: Faculty of Philosophy, pp. $45-56$.

- HOFFER, BATES (2002) "Language Borrowing and Language Diffusion: an Overview", Intercultural Communication Studies, Taylor \& Francis, vol. XI, no. 4, pp. 1 - 37.

- Horvat SKelin, anita (2005) „Posuđivanje u hrvatski hezik u dvama razdobljima", Suvremena Lingvistika, Zagreb, vol. LVII LVIII, no. 1 - 2, pp. $93-104$.

- Kajtazović, Enisa (2012) Engleske posudenice $i$ prevedenice u oblasti muzike u bosanskom/ hrvatskom/ srpskom jeziku, Master's thesis, <https://www.academia.edu/4152293/ 
Engleske_posudenice_i_prevedenice_u_oblasti_muzike_u_bosanskom_hrvatskom_srpskom_jeziku.>.

- Klajn, IVAn (2001) „Neologisms in Present-day Serbian”, International Journal of the Sociology of Language, De Gruyter, no. 151, pp. $89-110$.

- Milić, Mira (2004) "Uticaj engleskog jezika na srpski u procesu adaptacije sportske terminologije", Proceedings of the Fourth International Conference "Susret kultura", Faculty of Philosophy, Novi Sad.

- Millward, Celia - Hayes, Mary (2012) A Biography of the English Language, Centage Learning, Wadsworth.

- Omar, Adnan - Miah, Muhammed (2012) "Impact of Technology on Teens' Written Language", International Journal of Advanced Trends in Computer Science and Engineering, World Academy of Research in Science and Engineering, vol. I, no. 1, pp. 9-17.

- PrĆić, TVRTKo (2014) „Building Contact Linguistic Competence Related to English as the Nativized Foreign Language", System, Elsevier, vol XLII, pp. $143-154$.

- ŠEhoviĆ, Amela (2009) „Mjesto i funkcija anglicizama u savremenom bosanskom jeziku", Pismo, Bosansko filološko društvo, no. 7, pp. $122-135$.

- ŠLJiviĆ, Mersiha (2006) „English Influence on Bosnian Structures: Nouns as Premodifiers", Zbornik radova Filozofskog fakulteta u Tuzli, Tuzla, no. 7, pp. $180-191$.

- Thurairaj, Saraswathy - Hoon, Er Pek - Roy, Swagata Sinha, Fong, POK Wei (2015) „Reflections of Students' Language Usage in Social Networking Sites: Making or Marring Academic English", The Electronic Journal of e-Learning, Eric, vol XIII, no. 4, pp. $302-316$.

- Trask, Robert Lawrence (1996) Historical Linguistics, Arnold, London. 
- Vlajković, Ivana (2010) „Uticaji engleskog jezika na srpski na planu pravopisa, leksike i gramatike u komunikaciji na Fejsbuku", Komunikacija i kultura online, Univerzitet u Beogradu, Filološki fakultet, vol. I, no. 1, pp. $183-196$. 
Izvorni znanstveni članak

Primljen 26. I. 2019.

Nadja Skopljak - Vildana Dubravac

International Burch University Sarajevo, Odjel za engleski jezik International Burch University Sarajevo, Odjel za engleski jezik / Univerzitet u Zenici

\section{UTJECAJ ENGLESKOGA JEZIKA NA BOSANSKI I UPORABA ENGLESKIH RIJEČI U BOSANSKOME JEZIKU}

\section{Sažetak}

U ovoj studiji istražili smo utjecaj engleskoga kao globalnoga jezika na bosanski jezik, a poseban fokus stavljen je na uporabu engleskih riječi kod odraslih govornika bosanskoga jezika. Sukladno tomu, anketa je provedena među 200 ispitanika kako bi se stekao uvid u njihove preferencije kada su u pitanju izvorne bosanske riječi, strane engleske riječi i prilagođene engleske riječi. Analiza je otkrila da je engleski jezik stekao važan status u Bosni i Hercegovini, s obzirom na to da ga govornici nerijetko više preferiraju od izvornih termina sa sličnim ili jednakim značenjem. Nadalje, izgleda da ispunjavanje leksičkih praznina ne potiče posuđivanje, nego želju za prenošenjem poruke modernijega životnog stila.

Ključne riječi: bosanski jezik; međujezični utjecaj; engleski jezik; posuđivanje; preferencije 